\title{
MERINTIS BRANDING “KAMPUNG JAHE MOJOKERTO (KJM)" DI DESA GADING KECAMATAN JATIREJO, KABUPATEN MOJOKERTO
}

\author{
Arief Budhyantoro \\ Jurusan Teknik Kimia, Fakultas Teknik, Universitas Surabaya \\ email : budhyantoro@yahoo.com
}

\begin{abstract}
ABSTRAK
Gading is a village at sub-district of Jatirejo on Mojokerto district, East java. Gading is the village that had a characteristic as Siborian Region on Mojokerto district, which large is $2011 \mathrm{~km} 2$. The main agricultural potency in Gading is cane plantation that is coverage $70 \%$ area of Gading and jahe plantation at fields. The growth of economical level in Gading in ten years (2006-2016) is stagnan.This condition caused the increasing of society welfare is not significant, becaused Gading have no some factor can push the local economical growth. The government of Gading had an idea to build some local product with community base, the example is food and beverage products base on jahe. The idea was proposed because Gading had jahe as second main product in agriculture. The idea developed as program for "Village Branding" at Gading base on jahe agriculture. The region in Gading was branding based on jahe processing called as "Kampung Jahe Mojokerto (KJM)". The stub local product based on jahe processing are wedang jahe, jahe cookies and brownish jahe. This products has sale in regional market at around of Gading. The result of programe are The region of kampong jahe mojokerto, the community product based on herbal are wedang jahe, sinom, temulawak and jahe cookies.The obstacles to developed Gading as center of production of food and beverage based on jahe are the first, the products of food and beverage have no PIRT (certified for food and beverage for community product) and the packaging of products are not attractive to consumers.
\end{abstract}

Keywords : Kampung Jahe Mojokerto, Mojokerto, herbal food and beverage 


\section{PENDAHULUAN}

Desa Gading merupakan sebuah desa yang terletak di sebelah selatan kawasan wisata pusat Kerajaan Majapahit, Kecamatan Trowulan, Kabupaten Mojokerto. Potensi utama Desa Gading adalah pertanian dengan hasil utama tanaman tebu. Berdasarkan kondisi geografis Desa Gading memiliki ketinggian 20-30 mdpl (meter diatas permukaan laut) dengan iklim tropis dan kondisi curah hujan 45-55 mm/tahun. Desa Gading termasuk wilayah (Siborian) di Kabupaten Mojokerto, yaitu sebuah daerah yang mengalami perubahan perkembangan wilayah dari daerah agraris menjadi daerah industry atau juga disebut sebagai daerah "Cepat Tumbuh". Sebagai daerah siborian, perekonomian masyarakat Desa Gading sebagian besar sebagai petani, pedagang dan buruh pabrik. Namun demikian pertumbuhan ekonomi masyarakat Desa Gading termasuk lambat, hal ini disebabkan kondisi pertanian yang didominasi oleh tanaman tebu dengan masa panen setahun sekali dan per-dagangan yang digeluti masyarakat Desa Gading adalah pedagang kecil berupa usaha skala mikro-kecil. ${ }^{1}$

Desa Gading tidak memiliki produk unggulan khas yang bernilai ekonomis dan dapat memberikan dampak peningkatan perekonomian yang cukup besar bagi masyarakat. Pemerintah Desa Gading berencana untuk membangun sebuah kawasan yang memiliki produk-produk unggulan. Salah satu yang direncanakan adalah membangun kawasan budidaya jahe merah di Desa Gading dengan memanfaatkan lahan-lahan pekarangan masyarakat yang relative luas. Kendala pelaksanaan program pengem-bangan kawasan budidaya jahe merah adalah sebagai berikut, 1) belum ada road map pengembangan kawasan produk unggulan Desa Gading, 2) Tidak ada orang/tokoh yang ada di Desa Gading yang memiliki kemampuan untuk mendorong dan mendesain terwujudnya kawasan produk unggulan tersebut, 3) Kurangnya saranaprasarana yang dapat mendukung pengembangan kawasan produk unggulan baik berupa teknologi, metode dan jaringan bisnis dan 4) Rendahnya kualitas SDM, sehingga belum mampu mengorganisasi sebuah ide dan gagasan dengan baik.
Keinginan yang kuat dari pemerintah Desa Gading tidak dapat terwujud selama ini karena tidak adanya solusi terhadap kendala-kendala diatas.1,5

Kelompok PKK Desa Gading merupakan sebuah komunitas ibu-ibu yang dengan rutin menggelar kegiatan organisasi dan terlibat aktif dalam program-program pembangunan di Desa Gading. Beberapa aktivitas rutin yang dilakukan oleh kelompok PKK Desa Gading adalah kegiatan Posyandu anak, pelaksanaan POS PAUD, merintis bank sampah dan kegiatankegiatan rutin lainnya. Namun demikian secara dampak kegiatan kelompok ibu-ibu PKK ini belum bisa mendorong terbentuknya kawasan yang dapat menghasilkan sebuah produk unggulan., ${ }^{3,5,7}$

Tim Pemberdayaan kepada Masyarakat (PkM) Universitas Surabaya bekerjasama dengan pemerintahan Desa Gading, melakukan kesepakatan kerjasama untuk memberdayakan masyarakat di Desa Gading dalam membangun sebuah kawasan produk unggulan. Beberapa program yang dikerjakan oleh tim PkM UBAYA berdasarkan kesepakatan dengan pemerintah Desa Gading pada tahun 2018 antara lain, 1) Pengembangan produk unggulan desa yang berdampak pada peningkatan ekonomi masyarakat 2) Pengembangan bank sampah kearah tatakelola organisasi yang lebih baik dan benar dan 3) Pembentukan kandang sapi komunal milik desa yang bertujuan untuk meningkatkan kualitas peternakan sapi dan kesehatan lingkungan pemukiman warga. Pelaksanaan program Pengembangan produk unggulan Desa Gading di kemas dalam sebuah program besar dengan membentuk identitas khusus bagi sebuah wilayah (branding kawasan). Program branding kawasan yang dibuat dalam kegiatan pemberdayaan masyarakat Desa Gading adalah pengembangan "Kampung Jahe Mojokerto (KMJ)". Program ini dipusatkan di daerah dusun Sumber Kenongo, Desa Gading. Program ini bertujuan untuk mendorong terbentuknya sebuah kawasan terbatas di Desa Gading, yang produktif dalam menghaslkan produkproduk unggulan berupa olahan makanan dan minuman berbasis tanaman toga khususnya jenis empon-empon (misalnya: jahe, kunyit dan sebagainya). Keberadaan 
produk unggulan berupa olahan jahe diharapkan dapat berdampak pada peningkatan perekonomian masyarakat di Desa Gading. Kendala dari pelaksanaan program branding kawasan "Kampung Jahe Mojokerto" adalah 1) komitmen warga/anggota kelompok produktif dalam melaksanakan produksi produk-produk olahan 2) sebagian besar anggota kelompok masih memiliki mindset instan, dimana setiap aktivitas berharap langsung memberikan hasil atau dampak ekonomi dalam jangka pendek.

Mengapa harus "branding kawasan"? hal ini bertujuan untuk mendorong berkembangnya produk-produk unggulan Desa Gading, sehingga dapat memberikan nilai tambah ekonomi yang cukup tinggi bagi perekonomian masyarakat Desa Gading. Pada era per-saingan bisnis seperti saat ini, arti sebuah brand menjadi sangat penting, karena berkaitan dengan peningkatan minat bagi konsumen terhadap produk tertentu. Selain sebagai pembeda dan identitas bagi sebuah produk di tengah lautan produk sejenis, sebuah brand mempunyai makna psikologis dan simbolis yang istimewa di mata konsumen (Dewi, 2009: 3). Masyarakat Desa Gading berharap dengan adanya branding Kampung Jahe Mojokerto (KJM) diharapkan dapat mempercepat penetrasi pasar dari produk-produk olahan dari Kampung Jahe Mojokerto. Pemilihan branding Kampung Jahe Mojokerto (KJM) ini juga memenuhi syarat unik dan belum ada ditempat lain di Jawa Timur, khususnya di Kabupaten Mojokerto. Pada saat brand equity Kampung Jahe Mojokerto sudah terbentuk maka diharapkan akan menjadi milik masyarakat Desa Gading yang sangat berharga. Berdasarkan perspektif ini, konsumen akan memahami dari atribut merek Kampung Jahe Mojokerto sebagai atribut-atribut spesifik (Tjiptono, 2005:40). Wijaya (2013), menyatakan bahwa penguatan branding perlu dilakukan, apabila strategi mengkomunikasikan merek/brand tersebut berhasil, maka bukan hal yang tidak mungkin apabila brand knowledge brem Tongkat Mas sebagai brem khas Kabupaten Madiun menjadi semakin kuat terbentuk dalam benak konsumen.

Tujuan dari program branding Desa Gading dengan "Kampung Jahe Mojokerto" adalah untuk memberikan nilai tambah ekonomi terhadap segala produk yang dihasilkan oleh masyarakat Desa Gading, khususnya agar dikenal sebagai daerah penghasil jahe. Keberadaan nama branding dengan Kampung jahe Mojokerto ini diharapakan orang akan mengenal bahwa segala produk olahan makananminuman yang berbasis jahe adalah berasal dari Desa Gading, Kecamatan Jatirejo Kabupaten Mojokerto.

\section{METODE PELAKSANAAN}

Strategi yang dilakukan tim untuk membangun branding "Kampung Jahe Mojokerto (KJM)" melalui beberapa tahapan yaitu, 1) Metode pendekatan Edukasi yang meliputi proses pelatihan, workshop dan pendampingan praktek lapangan.

2) Metode pendekatan partisipatif masyarakat yang bertujuan untuk mengajak masyarakat berperan aktif dalam melaksanakan program branding kawasan Kampung Jahe Mojokerto, yaitu dengan melakukan proses-proses diskusi dengan kelompok PKK dan Perangkat Desa Gading, untuk menghasilkan kesepakatan terkait hal-hal yang harus dilakukan dalam pelaksanaan program branding kawasan Kampung Jahe Merah, 3) Metode pendekatan teknologi yang bertujuan untuk meningkatkan efisiensi proses dan kapasitas produksi, produk olahan makanan berbasis jahe dan membuat kemasan yang menarik bagi produk-produk olahan tersebut, 4) Metode pendekatan pemberdayaan masyarakat yang bertujuan untuk mendorong kemandirian warga dalam hal pelaksanaan pengem-bangan produkproduk olahan dari Kampung Jahe Mojokerto dan mereka diharap-kan mampu membangun pasar dan jaringan bisnis dari Kampung Jahe Mojokerto. Pada bagian ini dilakukan kegiatan pendampingan dan evaluasi pelaksanaan program branding Kampung Jahe Mojokerto.

Metode Pendekatan Pelatihan, beberapa kegiatan pelatihan yang dilakukan antara lain 1) Pelatihan pembuatan minuman tradisonal wedang jahe, temulawak dan sinom. 2) Pelatihan pembuatan kue kering (cookies) jahe. 3) Pelatihan pemasaran produk olahan dengan cara konvensional dan menggunakan media sosial. Strategi pemasaran produk Kampung Jahe Mojokerto dilakukan melalui 
beberapa cara yaitu melalui sosial media (facebook dan instagram), menitipkan produk di toko atau sekolahan, mempromosikan produk kepada dinas untuk dapat dijadikan sebagai suguhan pada saat rapat. Penerapan teknoogi kemasan dan labelling juga diharapkan dapat meningkatkan pemasaran produk olahan makananminuman jahe merah di Desa Gading. 4) Pelatihan pengelolaan kelompok usaha bersama Kampung Jahe Mojokerto (KJM). 5) Pelatihan pegelolaan keuangan bisnis Kampung Jahe Mojokerto.

Metode Pendekatan Partisipatif masyarakat, dilakukan dalam bentuk kegiatan diskusi kelompok (Focus Group Discussion $=$ FGD). Beberapa kegiatan diskusi yang dilakukan antara lain, 1) Diskusi membentuk kelompok UKM (KUBE) pembuat produk olahan makanan dan minuman berbasis jahe. 2) Menentukan tim pemasaran, strategi pemasaran produk awal dan strategi pengurusan PIRT. 3) Melakukan evaluasi terhadap proses produksi dan pemasaran produk awal, terkait kualitas produk dan penerimaan konsumen serta permasalahan yang harus diperbaiki dalam produksi dan pemasaran.

Metode Pendekatan Aplikasi Teknologi dilakukan dengan mengadakan peralatan untuk pembuatan produk olahan berupa TTG sederhana, yaitu peralatan untuk memproduksi minuman tradisional dalam skala besar yang dilengkapi dengan alat penyaring Buchner sederhana untuk menghilangkan endapan dalam minuman agar tidak mudah basi, pembuatan label dan kemasan yang menarik untuk produk yang dihasilkan.

Metode Pendekatan Pemberdayaan Masyarakat, metode ini dilakukan dengan melaukan pendampingan dan mendukung pelaksanaan proses produksi dan perbaikan sistem pemasaran dengan melakukan proses pengurusan PIRT dan perbaikan kemasan produk. Pengurusan PIRT untuk produk minuman wedang jahe, sinom dan cookies jahe, namun proses pelatihan PIRT dari dinas Kesehatan Kabupaten Mojokerto baru akan dilaksanakan pada bulan Maret 2019, hal ini dikarenakan adanya jumlah antrian UKM yang cukup banyak. Namun demikian proses analisa laboratorium terhadap produk-produk olahan berbasis jahe tersebut sudah mulai dilakukan pada saat ini untuk memenuhi persyaratan pengurusan PIRT pada bulan Maret 2019.

\section{HASIL PENELITIAN DAN PEMBAHASAN}

Pada pelaksanaan program pengembangan wilayah Desa Gading Kecamatan Jatirejo, Kabupaten Mojokerto karya utama yang dihasilkan ada dua hal yaitu pertama, Kelompok Usaha Bersama (KUBE) dengan label "Kampung Jahe Mojokerto (KJM)". Bentuk kelompok usaha bersama (KUBE) dipilih karena jenis olahan makanan-minuman jahe jumlahnya cukup banyak dan setiap produk olahan makanan-minuman akan dikelola oleh satu kelompok produksi yang berbeda-beda. Hal ini dilakukan agar jumlah keterlibatan masyarakat yang produktif dalam mendorong terbentuknya Kampung Jahe Mojokerto, cukup banyak. dan Kedua, produk-produk olahan makanan-minuman berbasis jahe. Produk olahan makanan dan minuman berbasis jahe ini diharapkan dapat menjadi produk unggulan di Desa Gading.

$$
\text { Kelompok Usaha Bersama }
$$
(KUBE) "Kampung Jahe Mojokerto", merupakan sebuah brand yang akan diangkat sebagai label utama dari semua produk olahan unggul berbasis jahe yang dihasilkan di Desa Gading. Hal ini dilakukan bertujuan, pertama, agar kontrol dan pengelolaan jenis dan kualitas produk dapat dilakukan dengan baik dan tertata dalam sebuah sistem yang dibangun, kedua, pemasaran yang dilakukan terhadap semua produk yang dihasilkan KJM dapat dilakukan secara terpadu dan terintegrasi, ketiga, KJM diharapkan dapat menjadi label yang dapat mengangkat nama Desa Gading di dalam berbagai hal sehingga dapat berdampak positip terhadap segala produk yang dihasilkan oleh Desa Gading. 


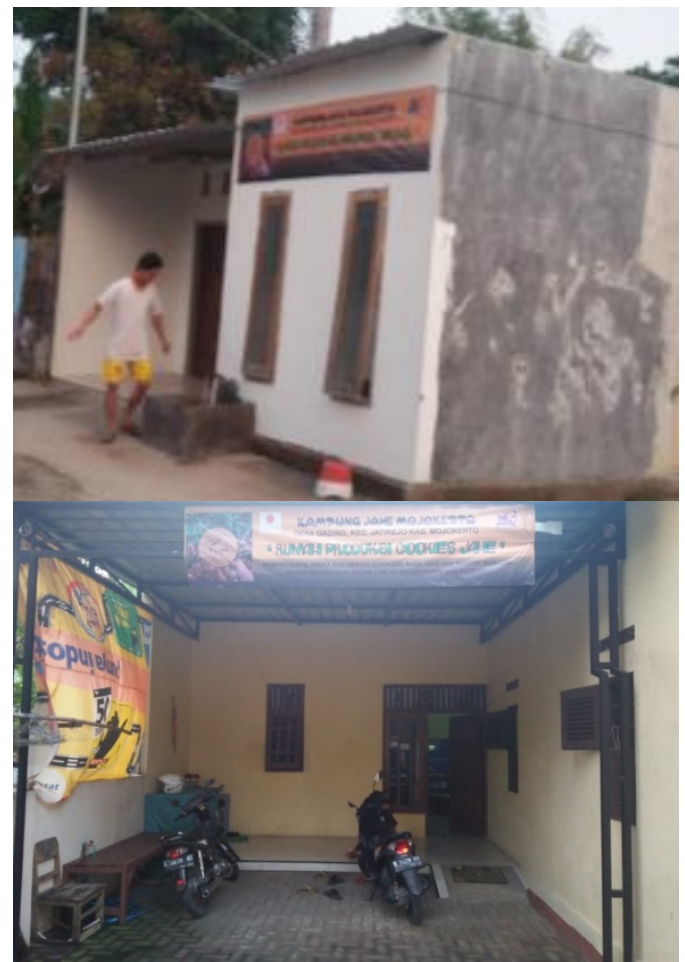

Gambar 1. Lokasi produksi produk olahan kue kering (cookies) dan Minuman herbal (wedang jahe) di kawasan Kampung jahe Mojokerto.

Metode pendekatan Aplikasi Teknologi, Produk olahan makanan berbasis jahe ini diharapkan menjadi produk-produk unggulan Desa Gading yang bernilai ekonomis dan dapat mengangkat nama Desa Gading di tingkat Jawa Timur khususnya.. Beberapa produk olahan makanan berbasis jahe yang akan di buat antara lain, minuman tradisional : wedang jahe, temulawak dan sinom, kue : kue kering (cookies) dan kue basah (brownis, bolu gulung).

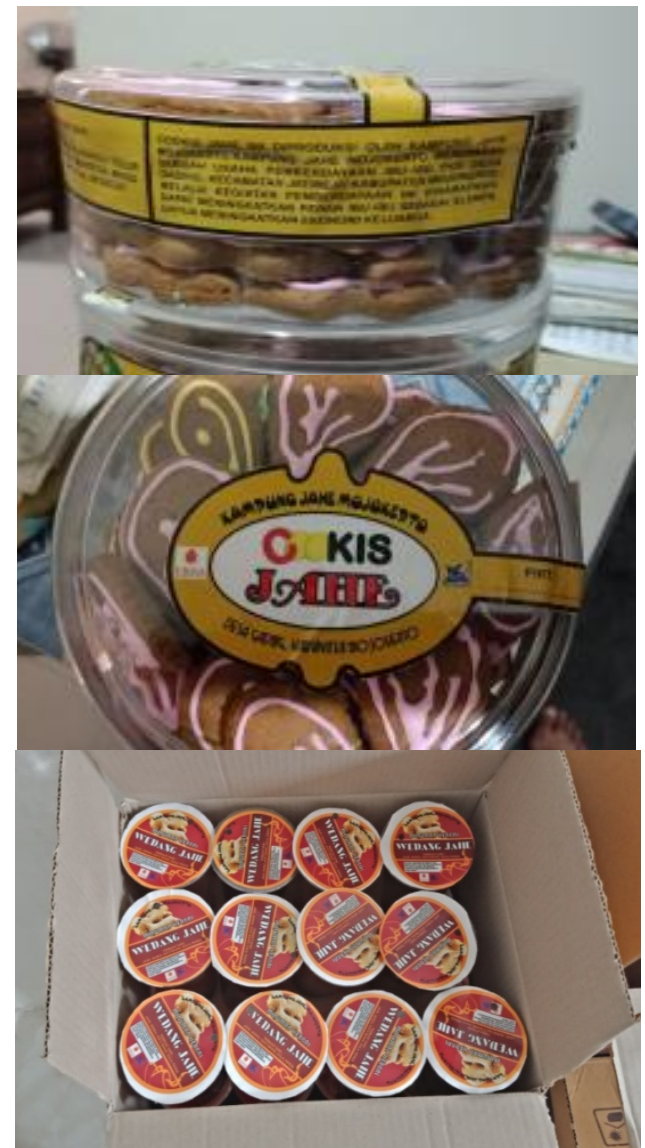

Gambar 2. Produk minuman herbal dan kue kering berbahan baku jahe

Untuk memudahkan dan memperlancar proses produksi produk olahan jahe (minuman dan cookies jahe) maka diberikan beberapa peralatan yang dimodifikasi. Misalnya tangki stainless steel untuk produksi minuman jahe, maka panci ditambahkan kran dan dudukan panci untuk mempermudah proses pengemasan. Pengadaan kemasan dan label produk yang menarik diharapkan dapat menjadi pendorong dalam hal peningkatan produk olahan kampung jahe mojokerto. Namun dari rencana olahan makanan yang akan dibuat produk yang telah dihasilkan adalah minuman tradisional dan kue kering jahe (cookies). Hal penting yang dikembangkan dalam proses produksi produk olahan makanan berbasis jahe ini adalah metode produksi, metode pengemasan dan TTG produksi yang digunakan khususnya untuk produk minuman tradisional. 


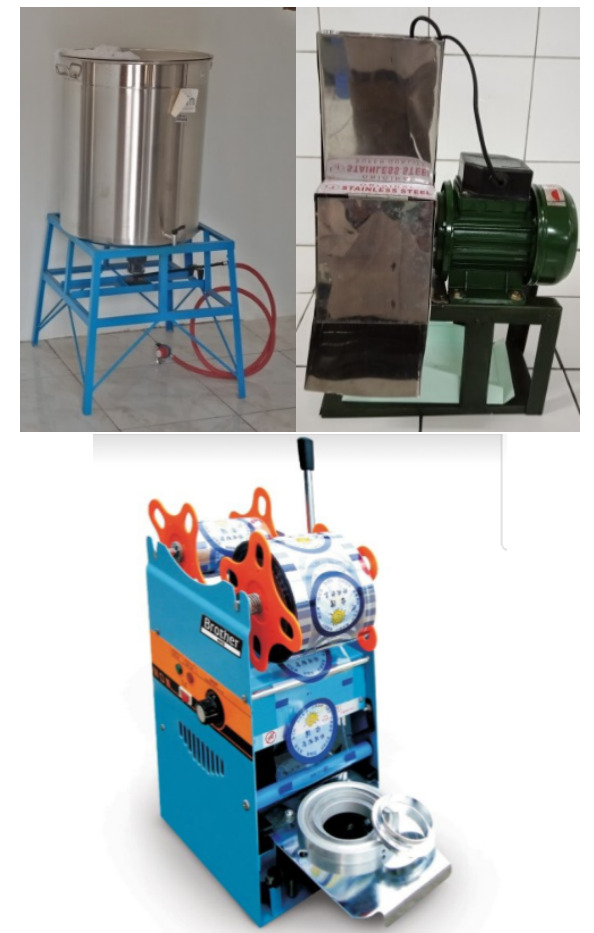

Gambar 3. Peralatan yang diadakan untuk produksi minuman herbal di UKM anggota KUBE Kampung Jahe Mojokerto.

Karya utama dalam kegiatan ini adalah terbentuknya KUBE "Kampung Jahe Mojokerto (KJM)" yang merupakan kumpulan dari UKM olahan produk makanan-minuman berbahan jahe. Kelompok Usaha Bersama (KUBE) "Kampung Jahe Mojokerto" dibentuk dalam rangka sebagai branding bagi produk olahan Desa Gading sekaligus sebagai identitas khas dari Desa Gading yang diharapkan berdampak pada nilai tambah ekonomi terhadap segala produk yang dihasilkan oleh Desa Gading. Proses pembentukan branding Kampung Jahe Mojokerto diawali dengan dilakukan diskusi kelompok antara kelompok PKK dan Pemerintahan Desa Gading, untuk menentukan produk unggulan desa yang diinginkan dan bagaimana cara membentuk brand produk unggulan yang berdaya saing dipasaran. Branding Kampung Jahe Mojokerto muncul sebagai wujud adanya keinginan pemerintah Desa Gading untuk mendorong masyarakat Desa Gading mengembangkan budidaya tanaman jahe merah sebagai komoditas agro yang memiliki nilai ekonomi tinggi. Pada saat diskusi bersama perangkat Desa dan Kelompok PKK Desa Gading, muncul usulan perlunya produk olahan makanan berbasis jahe sebagai bukti bahwa Desa Gading adalah pusat budidaya tanaman jahe merah. Hal ini merupakan sebuah gagasan yang sangat baik, karena dengan branding diharapakan jika ada produk olahan yang diterima dimata konsumen, maka produk lainnya dapat terdampak positip dari branding tersebut.

Tahapan pembentukan produk unggulan Desa Gading berbasis olahan jahe, diawali dengan diproduksinya beberapa makanan olahan berbasis jahe yaitu 1) produk minuman tradisional dalam bentuk wedang jahe dan sinom 2) Kue kering (cookies) jahe. Tahapan yang dilakukan dalam menghasilkan produk minuman tradisional dan cookies jahe ini meliputi :

1) Kegiatan diskusi kelompok, bertujuan untuk,

- membentuk kelompok yang akan memproduksi produk olahan tersebut.

- menentukan produk minuman herbal/cookies jahe yang diperkirakan paling laku dan mudah untuk diproduksi, menentukan ukuran dan bentuk kemasan.

- menentukan cara memasarkan produk yang dihasilkan.

2) Kegiatan pelatihan pembuatan produk minuman tradisional jahe/cookies jahe, hal ini bertujuan untuk meningkatkan pengetahuan dan skill kepada para kelompok UKM minuman herbal tradisional/cookies jahe sehingga diharapkan masyarakat dapat menghasilkan produk secara mandiri dengan kualitas yang baik. 


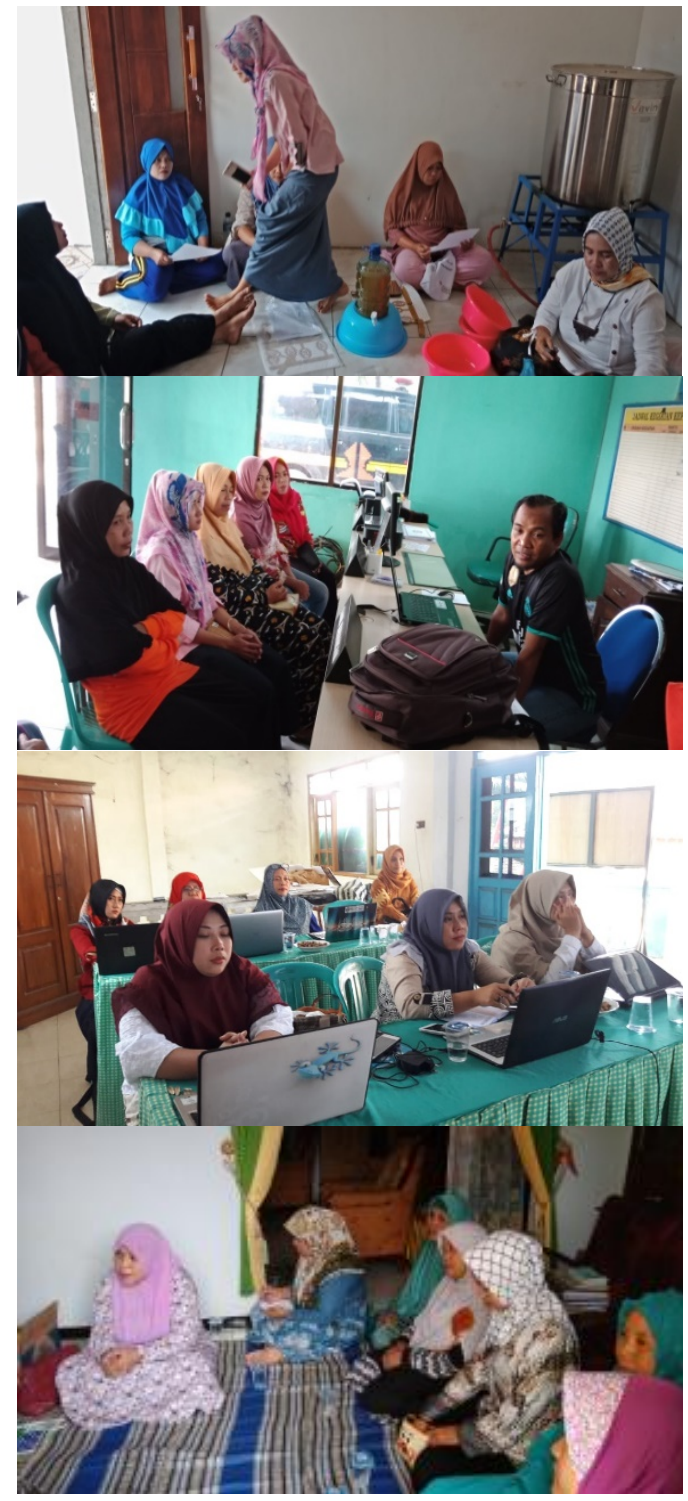

Gambar 4. Kegiatan FGD dan pelatihan yang dilakukan untuk pembentukan KUBE Kampung Jahe Mojokerto dan pembentukan kelompok penghasil produk olahan berbasis jahe.

3) Proses produksi perdana minuman herbal tradisional berbasis jahe skala industri rumahan. Beberapa peralatan dan metode yang digunakan dalam pengembangan produk minuman herbal berupa,

- Pengadaan alat panci stainless steel "food grade" dengan volume $160 \mathrm{~L}$ yang dilengkapi dengan kran untuk pengemasan pada bagian bawah panci.

- Cup Sealer dan metode pengemasan panas (hot filling) pada kemasan cup plastic. Metode hot filling ini menjamin untuk mencegah terjadinya kontaminasi oleh kapang, jamur dan bakteri yang dapat menyebabkan terjadinya pembusukan produk lebih cepat.

4) Pemberian modal produksi awal, modal awal ini diberikan kepada 3 kelompok UKM pelaksana masing-masing memperoleh bantuan modal awal sebesar Rp. 1 juta. Hal ini bertujuan untuk menjamin kontinyuitas produksi minuman herbal wedang jahe oleh UKM tersebut.

5) Studi pasar sederhana, dilakukan untuk menentukan kualitas produk minuman wedang jahe yang dihasilkan. Berdasarkan hasil uji kesukaan konsumen terhadap 100 tester yang diberikan diperoleh hasil sebagai komentar konsumen berikut,

Tabel 1 : Respon konsumen minuman herbal "Wedang Jahe" produksi Kampung Jahe Mojokerto pada 100 orang responden.

\begin{tabular}{|c|l|c|}
\hline NO & \multicolumn{1}{|c|}{ Jenis Komentar } & $\begin{array}{c}\text { Jumlah } \\
\text { orang }\end{array}$ \\
\hline 1 & $\begin{array}{l}\text { Rasa Enak dan Pedasnya } \\
\text { pas }\end{array}$ & 43 \\
\hline 2 & $\begin{array}{l}\text { Rasa hangat dibadan } \\
\text { terasa }\end{array}$ & 16 \\
\hline 3 & Rasa manis terlalu pekat & 12 \\
\hline 4 & $\begin{array}{l}\text { Rasa kayu manis terlalu } \\
\text { kuat }\end{array}$ & 20 \\
\hline 5 & Masih ada rasa getir & 14 \\
\hline 6 & Produk layak dijual & 82 \\
\hline 7 & $\begin{array}{l}\text { Produk belum layak } \\
\text { djual }\end{array}$ & 6 \\
\hline 8 & $\begin{array}{l}\text { Tidak menjawab kelaya- } \\
\text { kan produk }\end{array}$ \\
\hline
\end{tabular}

Berdasarkan hasil komentar konsumen diatas maka dapat disimpulkan bahwa produk minuman wedang jahe tersebut sudah layak dijual dengan melakukan beberapa perbaikan terhadap resep pembuatan sehingga diharapkan diperoleh perbaikan rasa yang sesuai dengan keinginan konsumen. Namun demikian untuk merespon tanggapan yang kurang baik terhadap kualitas dan kelayakn produk minuman wedang jahe maka 
beberapa hal yang perlu diperbaiki adalah mengurangi jumlah gula, jumlah kayu manis dan jumlah sereh untuk mengurangi rasa manis dan getir dalam wedang jahe.

Selain permasalahan rasa terdapat permasalahan lain yang dihadapi, yaitu daya tahan minuman wedang jahe hanya 34 hari saja, setelah itu produk akan berasa masam dan berbusa. Hal ini diperkirakan karena produk masih banyak mengandung fraksi padat yang mengendap. Hal ini dibuktikan dari hasil penjualan pada periode pertama dari sebanyak 550 cup minuman wedang jahe yang diproduksi diperoleh hasil sebagai berikut, 230 cup berhasil dijual dan 320 cup tidak laku karena produk keburu basi. Minuman wedang jahe tersebut mengalami basi setelah empat (4) hari dari masa produksi. Hal ini menjadi evaluasi bagi tim pendamping untuk membuat produk yang tahan dalam waktu yang cukup lama.

Hal yang mengakibatkan wedang jahe cepat basi adalah kurangnya higiensi pada saat proses pengemasan, yaitu tidak dilakukan sterilisasi terhadap gelas dan larutan minuman telah dingin sehingga dimungkinkan terkontaminasi oleh kapang dan jamur sangat besar. Perbaikan proses yang dilakukan adalah dengan melakukan sterilisasi cup plastik menggunakan bahan antiseptik yaitu peracetic acid atau pemanasan suhu $70 \mathrm{oC}$ terhadap cup plastik. Perbaikan terhadap proses pengemasan juga dilakukandengan menggunakan metode hot filling agar tidak terjadi kontaminasi produk oleh jamur, kapang dan bakteri baik dari udara maupun dari kemasan yang digunakan.

Saat ini produksi minuman wedang jahe rerata per-bulan adalah 2000 cup dengan omzet rerata bisnis wedang jahe adalah Rp. 3.000.000/bulan. Jumlah ini masih relatif kecil dibandingkan pasar yang ada, hal ini disebabkan karena proses promosi masih blum berjalan dengan baik, penggunaan minuman wedang jahe masih khusus di kegiatan-kegiatan rapat dan orang yang punya hajat. Pasar untuk anak-anak tidak bisa tergarap karena rasa yang kurang cocok untuk anak, sehingga perlu difikirkan produk lain yang disukai oleh anak-anak, sehingga diharapkan dapat meningkatkan omzet kelompok UKM minuman herbal.
6) Proses produksi cookies jahe skala industri rumahan, beberapa hal yang dilakukan dalam menginisiasi produksi cookies jahe adalah sebagai berikut,

7) Pengadaan set peralatan produksi cookies jahe untuk kelompok UKM cookies. Peralatan yang diberikan berupa oven bakar ukuran sedang, Loyang, mixer, kemasan toples, label kemasan dan aneka cetakan cookies aneka bentuk tematik.

8) Selain peralatan jugabahan-bahan untuk produksi cookies jahe, hal ini untuk mendorong kelompok UKM baru ini untuk dapat segera membuat cookies dan menjual hasilnya.

9) Pemberian modal produksi awal, modal awal ini diberikan kepada 2 kelompok UKM pelaksana masing-masing memperoleh bantuan modal awal sebesar Rp. 1 juta. Hal ini bertujuan untuk menjamin kontinyuitas produksi cookies jahe oleh UKM tersebut.

Proses produksi cookies jahe ini tidak selancar produksi minuman herbal wedang jahe, hal ini disebabkan karena produk cookies hanya banyak dibutuhkan pada saat lebaran idul fitri saja, namun demikian proses pemasaran saat ini dilakukan dengan menitipkan produk di toko oleh-oleh khas Mojokerto di kawasan kota Mojokerto.

\section{Kendala Pelaksanaan Program}

Beberapa kendala yang dihadapi oleh tim dalam memberdayakan masyarakat anggota kelompok KUBE Kampung Jahe Mojokerto adalah sebagai berikut :

1) Sikap percaya kepada tim yang masih kurang kuat diawal pelaksanaan program, khususnya dalam hal proses produksi dan pemasaran. Hal ini terjadi karena kecenderungan masyarakat untuk menyerahkan seluruh proses kepada tim dan mereka hanya tinggal mengikuti mengakibatkah laju pencapaian kemandirian kelompok KUBE Kampung Jahe Mojokerto kurang begitu seperti yang diharapkan seperti awal mula kesepakatan antara tim pendamping dan mitra program. Namun demikian sampai pada kondisi terakhir pada bulan Oktober 2018, 
UKM minuman herbal telah berjalan rutin walaupun omzet produksi yang dihasilkan belum seberapa banyak.

2) Lamanya waktu pengurusan PIRT menjadi kendala bagi kelompok untuk dapat menjual produknya melalui sentra-sentra penjualan oleh-oleh khas Mojokerto, karena sebagian besar took tersebut mau menerima penitipan penjualan jika produk telah memiliki PIRT. Sedangkan pengurusan PIRT produk-produk dari KUBE Kampung Jahe Mojokerto baru keluar pada bulan Maret 2019. Solusi yang dilakukan sementara ini penjualan dilakukan di sekolah-sekolah dan pesanan oleh warga sekitar. Sedangkan produksi cookies jahe belum bisa dilakukan secara kontinyu, karena penjualan harus menunggu PIRT terlebih dahulu.

3) Proses promosi Kampung jahe Mojokerto belum berjalan dengan baik, karena produk yang dimiliki baru terbatas 2 jenis yaitu minuman herbal dan cookies jahe. Sedangkan rencana akan diproduksi 9 jenis produk olahan makanan dan minuman berbahan jahe.

\section{KESIMPULAN}

Produk olahan minuman herbal tradisional berbahan jahe saat ini merupakan satu-satunya produk yang dapat diproduksi secara rutin setiap hari, sebagai produk unggulan dari Kampung Jahe Mojokerto.

Branding Kampung Jahe Mojokerto belum berjalan seperti yang diharapkan, hal ini disebabkan karena produk unggulan yang dihasilkan masih terbatas, sehingga proses promosi secara alamiah di kawasan tersebut tidak berjalan dengan baik.

\section{DAFTAR PUSTAKA}

BAPPEDA Kabupaten Mojokerto, 2017, Rencana Strategis Badan Perencanaan Pembangunan Daerah (RPJMD) Kabupaten
Mojokerto Tahun 2016 - 2021, Perpustakaan BAPPENAS

Zendy Tedja Wijaya, 2014, Penyusunan dan Implementasi Strategi Branding Produk Kuliner dalam Membentuk Brand Knowledge sebagai Oleh-Oleh Khas Kabupaten Madiun, journal ilmiah.uajy no 18, vol. 2, 2014

Rendy Gunawan, Aristarchus PK dan Margana, 2013, Perancangan Desti-nation Branding Desa Poncokusumo-Malang, Jurnal DKV Adiwarna Vol 1, No 2 (2013): ADIWARNA Publisher: Jurnal DKV Adiwarna

Destination Branding Blueprint-TDL (2012). Destination Branding Blueprint, Diunduh 18 Maret 2013 dari http://destinationbranding.com/de stinationbranding-blueprint.

Dewi, Ike Janita, 2009, Creating \& Sustaining Brand Equity, Yogyakarta: Asmara Books

Destination Branding, 2008, Majalah $B R A N D N A$, Vol. 2, No 6, hal 1739.

Dadi Adriana, Fandy Tjiptono dan Gregorius Chandra. 2008. Pemasaran Strategik, Yogyakarta : Andi.

Syafrizal Helmi, 2007, Regional Branding: Strategi Memasarkan Daerah, WAHANA HIJAU Jurnal Perencanaan \& Pengembangan Wilayah, Vol.2, No.3, April 2007

Fandy Tjiptono, 2005, Brand Management and Strategy, Yogyakarta: ANDI 